\title{
Effects of Dietary Glucogenic Precursors and Fat on Feed Intake and Carbohydrate Status of Transition Dairy Cows*
}

\author{
R. S. Patton, ${ }^{1}$ C. E. Sorenson, ${ }^{2}$ and A. R. Hippen ${ }^{2}$ \\ ${ }^{1}$ Galisteo, New Mexico 87540 \\ ${ }^{2}$ Dairy Science Department, South Dakota State University, Brookings 57007
}

\begin{abstract}
Twenty-four multiparous Holstein cows were used to determine the effects of dietary fat and glucose precursors on energy status and lactation. The treatment group (T) received $409 \mathrm{~g} / \mathrm{d}$ (DM basis) of a combination of calcium salts of fatty acids, calcium propionate, and propylene glycol. The control group (C) received $409 \mathrm{~g} /$ $\mathrm{d}$ of a mixture of calcium salts of fatty acids and ground barley from $14 \pm 0.9 \mathrm{~g} / \mathrm{d}$ before until $21 \mathrm{~d}$ after calving. Dry matter intake was greater ( 16.1 vs. $13.6 \pm 1.3 \mathrm{~kg} /$ d) for $\mathrm{T}$ than $\mathrm{C}$ during the last week prepartum and did not decrease for $\mathrm{T}$ from the previous week, whereas, in C, DM intakes decreased by $3.2 \mathrm{~kg} / \mathrm{d}$. Production of milk and milk fat did not differ. There was a tendency for lower protein and increased lactose concentrations in milk from T cows. Milk fat percentage was lower in $\mathrm{T}$ at $\mathrm{d} 7$ (5.5 vs. $6.4 \pm 0.5 \%)$ and 28 (4.4 vs. $5.5 \pm 0.5 \%)$ of lactation. Liver lipid content was numerically lower (7.9 vs. $9.2 \pm 0.9 \%$ ) and glycogen content was significantly higher ( 2.4 vs. $2.0 \pm 0.1 \%$ ) in $\mathrm{T}$ vs. $\mathrm{C}$ cows on $\mathrm{d} 7$ of lactation. Concentrations of nonesterified fatty acids were lower in blood of $\mathrm{T}$ cows on $\mathrm{d} 2$ and 7 of lactation. Over all time points, blood glucose concentrations were higher in T cows pre- (70.75 vs. $62.1 \pm 1.3 \mathrm{mg} / \mathrm{dL})$ and postpartum ( 60.1 vs. $56.2 \pm 1.1 \mathrm{mg} / \mathrm{dL}$ ). Insulin concentrations in blood were greater for T (397 vs. $314 \pm 48$ $\mathrm{pg} / \mathrm{mL}$ ) both pre- and postpartum. Feeding glucose precursors in combination with rumen inert lipids, compared with feeding barley in combination with the lipids for $2 \mathrm{wk}$ before parturition and $3 \mathrm{wk}$ postpartum helped avoid prepartum feed intake depression and increased blood glucose and insulin and decreased blood NEFA. (Key words: glucose precursor, dietary fat, ketosis, dairy cow)
\end{abstract}

Abbreviation key: $\mathbf{C}=$ control, $\mathbf{T}=$ treatment.

\footnotetext{
Received September 12, 2003.

Accepted February 25, 2004.

Corresponding author: A. R. Hippen; e-mail: arnold.hippen@ sdstate.edu.

*Published with the approval of the Director of the South Dakota Agricultural Experiment Station as Publication Number 3380 of the Journal Series.
}

\section{INTRODUCTION}

Contemporary dairy cows are able to produce milk beyond our ability to feed them in early lactation. Much research is focused on when lactation begins and negative energy balance is seemingly inevitable, but few studies follow diet comparisons throughout both prepartum and postpartum periods, and no studies have evaluated glucogenic precursors fed in conjunction with rumen inert fat in the transition dairy cow. In the newborn rat, Ferre et al. (1978) investigated hypoglycemia and depressed gluconeogenesis elicited by a 16 -h fast from birth. It was demonstrated that glucogenic precursors injected interperitoneally increased blood glucose $200 \%$ over fasted controls. Moreover, glucogenic precursors administered to rat pups fed triglycerides at the same time increased blood glucose over $400 \%$, suggesting that oral fat supplement potentiates the glycemic effect of glucogenic precursors. Lomax et al. (1986) demonstrated a similar response, in vitro, citing sheep hepatocyte data where fatty acids stimulated the entry of propionate carbon into the glucogenic pathway. A report of field data by Patton and Poley (1996) provided evidence that this benefit may be operative in the transition cow.

In this report, a trial is described wherein glucogenic precursors fed with fat were tested as a dietary supplement for transition cows. Characteristics of dietary bypass fat recommend it for this use. Fat that escapes the rumen and arrives at the small intestine enters the lymphatic system as chylomicrons, which do not add to the hepatic lipid accumulation, as liver lacks lipoprotein lipase (Emery et al., 1992). The mammary gland, the predominant energy sink in the transition cow, has abundant lipoprotein lipase (Havel, 1987) and readily extracts blood lipids. In contrast to these advantages, dietary fat fed in the absence of glucogenic precursors was reported to decrease DMI prepartum (Grum et al., 1996) and postpartum (Jerred et al., 1990).

Reasons to consider feeding of glucogenic precursors to transition cows are several. Propionate is the major glucogenic VFA of the rumen, and the depressed appetite as the cow nears parturition can diminish propionate availability (Baird et al., 1980). Propionate inhib- 
its hepatic lipid oxidation (Lomax et al., 1983; Jesse et al., 1986; Armentano et al., 1991), and it is antiketogenic (Drackley, 1999). Also, unlike other glucogenic precursors, propionate is not down-regulated by insulin (Brockman, 1990), and liver uptake of propionate is preferential and highly efficient (Bergman, 1990). As a precursor of ruminal propionate, propylene glycol is a glucogenic precursor and is a commonplace therapy for energy deficit in milk cows (Studer et al., 1993; Grummer et al., 1994; Christensen et al., 1997). Informed by the reports of Ferre et al. (1978) and Lomax et al. (1986), where glycemic effect was enhanced by oral fat, and given the advantages of dietary fat and the several benefits of propionate, our hypothesis was that fat and glucogenic substrates fed together would have an additive benefit for the transition cow.

\section{MATERIALS AND METHODS}

Twenty-four multiparous cows (12 per treatment) of the South Dakota State University Dairy Research and Training Facility herd were used in an experiment conducted from November 1999 to May 2000. Cows were cared for according to guidelines of the South Dakota State University Institutional Animal Care and Use Committee. Cows were blocked according to calving dates and previous lactation 305-d mature equivalent and assigned to treatments at $21 \mathrm{~d}$ before calving, or as close to that day as allowed by records and biologic variation. Starting at $14 \pm 0.9 \mathrm{~d}$ before calving, each cow was fed either a conventional prefresh diet (Table 1) top dressed daily with either $409 \mathrm{~g}$ (DM basis) of a barley and fat supplement (135 $\mathrm{g}$ of calcium salts of fatty acids; Megalac, Church and Dwight Co., Princeton, NJ; plus $274 \mathrm{~g}$ of ground barley; control = C), or with $409 \mathrm{~g}$ (DM basis) of a combination of propionate, propylene glycol, and Megalac in pellet form (Metaxerol; Pestell Minerals and Ingredients, New Hamburg, Ontario, Canada; treatment $=\mathbf{T}$ ). Treatments were fed until 21 DIM. Ingredient compositions of the far-off dry and lactating cow diets are also described in Table 1. Feed was allocated using a Calan Data Ranger (American Calan Inc., Northwood, NH), and intake was determined for each cow with a Calan door feeding system.

Cows were fed ad libitum at $0800 \mathrm{~h}$, and feed intake was recorded daily from -21 to 70 DIM. Samples of diets were collected weekly, made into composites by month, and analyzed for content of DM, CP, EE, Ash, $\mathrm{ADF}, \mathrm{NDF}$, calcium, and phosphorus by a commercial laboratory (Oscar E. Olson Biochemistry Laboratories, Brookings, SD; Table 2). Milk samples were collected at 0600 and $1800 \mathrm{~h}$ at $7,14,21,28,35,42,49,56$, 63 , and 70 DIM and made into daily composites for determination of content of protein, fat, lactose (AOAC,
1997; Multispec; Foss Food Technology Corp., Eden Prairie, MN), and SCC (AOAC, 1997; Foss-o-matic 90, Foss Food Technology Corp.) by a commercial laboratory (Valley Queen Cheese, Milbank, SD). Body weights and body condition scores were recorded at $-14 \pm 0.9$, 0,28 , and 70 DIM.

Liver biopsies were scheduled to be collected by trocar and aspiration between the 11th and 12th rib (Smith et. al., 1997), 4 to $5 \mathrm{~h}$ after feeding at $1300 \mathrm{~h}$, on $\mathrm{d}-14$, -2 , or as soon as possible before calving, and at 2,7 , 14 , and 28 DIM. Actual prepartum collections occurred at $\mathrm{d}-14 \pm 0.9$ and $-3 \pm 0.6$. Samples were frozen at $-80^{\circ} \mathrm{C}$ until quantification for total lipid (Mills et al., 1986) and glycogen (Derling et al., 1987). One cow passed her predicted calving date by more than $7 \mathrm{~d}$ and had a second liver biopsy for the -2-d sample at $d-3$. Blood was sampled from the coccygeal vein immediately before liver biopsy at $-14 \pm 0.9,-7 \pm 0.9,-3 \pm 0.6,2,7$, 14 , and 28 DIM and at $1300 \mathrm{~h}$ at 21 DIM. One cow receiving the treatment and 2 cows receiving the control diet calved before predicted calving dates and were omitted from statistical analysis of liver and blood variables for that day. Blood was collected into 10-mL Vacutainer tubes (Becton Dickinson and Co., Rutherford, $\mathrm{NJ}$ ) containing $\mathrm{Na}_{2}$-EDTA and stored on ice for a maximum of $2 \mathrm{~h}$ while plasma was being prepared. Aprotinin (Boehringer-Mannheim, Indianapolis, IN) was added at $500 \mathrm{KIU}$ to $1 \mathrm{~mL}$ of plasma to be analyzed for glucagon. Plasma was stored at $-20^{\circ} \mathrm{C}$ until analyzed for concentration of glucose (kit number 315, Sigma Chemical Co., St. Louis, MO), NEFA (Smith et al., 1997), and BHBA (Williamson and Melanby, 1974). Glucagon and insulin were quantified by radioimmunoassay (Diagnostic Products Corp., Los Angeles, CA). Concentrations of each hormone were each determined in a single assay and the intraassay coefficients of variation were 3.6 and $7.1 \%$ for insulin and glucagon, respectively.

Cows were monitored daily for clinical signs of ketosis (Ketostix, Bayer Corp., Tarrytown, NY). Health records were kept throughout the study to register the incidence of milk fever, retained placenta, metritis, displaced abomasum, ketosis, mastitis, and foot problems. Reproductive performance was evaluated by collecting the following data: days to first service, days open, and services per conception.

Milk production and DMI were reduced to weekly means before statistical analysis. Weekly means and actual sampling day values for liver, blood, and milk composition data were evaluated using the MIXED procedure for repeated measures by SAS (SAS, 1996). The variance for cow, nested within treatment, was used as the error term to test the main effect of treatment. Treatment effects at specific days were determined by 
Table 1. Ingredient composition of experimental diets. ${ }^{1}$

\begin{tabular}{|c|c|c|c|c|c|}
\hline \multirow[b]{2}{*}{ Ingredient, $\mathrm{kg}$ of $\mathrm{DM} / \mathrm{d}$} & \multirow{2}{*}{$\frac{-60 \text { to }-14 \text { DIM }}{\text { All cows }}$} & \multicolumn{2}{|c|}{-14 to $0 \mathrm{DIM}$} & \multicolumn{2}{|c|}{0 to $28 \mathrm{DIM}$} \\
\hline & & Control & Treatment & Control & Treatment \\
\hline & & & $\mathrm{DM}, \%$ & & \\
\hline Grass hay $^{2}$ & 54.5 & 28.2 & 28.2 & - & - \\
\hline Alfalfa hay ${ }^{3}$ & - & - & - & $\overline{19} .0$ & $\overline{19} .0$ \\
\hline Corn silage 4 & 30.7 & 32.6 & 32.6 & 26.8 & 26.8 \\
\hline Cottonseed & 4.94 & 4.25 & 4.25 & 10.0 & 10.0 \\
\hline High moisture corn ${ }^{5}$ & 4.43 & 20.7 & 20.7 & 21.6 & 21.6 \\
\hline Soybean meal, $48 \%$ & 3.94 & 12.3 & 12.3 & 10.5 & 10.5 \\
\hline Dry distillers grain & - & - & - & 4.10 & 4.10 \\
\hline Soy hulls & - & - & - & 4.92 & 4.92 \\
\hline Calcium carbonate & 0.35 & 0.67 & 0.67 & 1.44 & 1.44 \\
\hline Magnesium oxide & 0.22 & 0.45 & 0.45 & 0.18 & 0.18 \\
\hline Sodium bicarbonate & - & - & - & 0.54 & 0.54 \\
\hline Salt & 0.22 & 0.17 & 0.17 & 0.09 & 0.09 \\
\hline Monocalcium phosphate & 0.43 & 0.30 & 0.30 & 0.63 & 0.63 \\
\hline Dry cow premix 6 & 0.30 & 0.28 & 0.28 & & \\
\hline Lactation premix ${ }^{7}$ & - & - & - & 0.11 & 0.11 \\
\hline Metaxerol $^{8}$ & - & - & 0.45 & - & 0.45 \\
\hline Megalac ${ }^{9}$ & - & 0.13 & - & 0.13 & - \\
\hline Barley & - & 0.32 & - & 0.32 & - \\
\hline
\end{tabular}

${ }^{1}$ Diets were fed as a TMR as described. Metaxerol or Megalac and barley were top-dressed at quantities listed. From 21 to 120 DIM, all cows fed the control lactation diet without bypass fat or barley.

${ }^{2}$ Grass hay assay, DM, \%: 11.7 moisture, 9.0 CP, 36.9 ADF, 53.8 NDF, 0.69 Ca, 0.25 Phos, 0.16 Mg, and $1.41 \mathrm{~K},\left(\mathrm{NE}_{\mathrm{L}} 1.63 \mathrm{Mcal} / \mathrm{kg}\right)$.

${ }^{3}$ Alfalfa hay assay, DM, \%: 9.4 moisture, 23.9 CP, 29.7 ADF, 38.2 NDF, $1.36 \mathrm{Ca}, 0.36 \mathrm{P}, 0.23 \mathrm{Mg}$, and $2.07 \mathrm{~K},\left(\mathrm{NE}_{\mathrm{L}} 1.518 \mathrm{Mcal} / \mathrm{kg}\right)$.

${ }^{4}$ Corn silage assay, DM, \%: 72.3 moisture, 8.9 CP, 24.2 ADF, 46.6 NDF, 0.24 Ca, 0.21 P, $1.12 \mathrm{~K}$, and 0.14 $\mathrm{Mg},\left(\mathrm{NE}_{\mathrm{L}} 1.63 \mathrm{Mcal} / \mathrm{kg}\right)$.

${ }^{5}$ Processed.

${ }^{6}$ Dry Cow Supreme, Land O’ Lakes, Fort Dodge, IA. Assay, DM: $1.0 \% \mathrm{Ca}, 4.5 \% \mathrm{Mg}, 1.0 \% \mathrm{~K}, 1.0 \% \mathrm{~S}, 3150$ $\mathrm{ppm}$ of $\mathrm{Fe}, 1890 \mathrm{ppm}$ of $\mathrm{Cu}, 38 \mathrm{ppm}$ of Co, $8280 \mathrm{ppm}$ of Mn, $8280 \mathrm{ppm}$ of Zn, 454,000 IU/kg of vitamin A, $90,900 \mathrm{IU} / \mathrm{kg}$ of vitamin D, and $3636 \mathrm{IU} / \mathrm{kg}$ of vitamin E.

${ }^{7}$ Dairy Micro Premix, Land O' Lakes, Fort Dodge, IA. Assay, DM: 10\% Mg, 9840 ppm of Fe, 120 ppm of $\mathrm{Cu}, 26,000 \mathrm{ppm}$ of Mn, 26,000 ppm of Zn, $400 \mathrm{ppm}$ of I, $140 \mathrm{ppm}$ of Se, 909,000 IU/kg of vitamin A, 182,000 $\mathrm{IU} / \mathrm{kg}$ of vitamin D, and $2424 \mathrm{IU} / \mathrm{kg}$ of vitamin $\mathrm{E}$.

${ }^{8}$ Pestell Ingredients, New Hamburg, ONT, Canada. Assay: 8\% moisture, $7 \%$ CP, and $30 \%$ fat.

${ }^{9}$ Church and Dwight Co., 469 North Harrison Street, Princeton, NJ 08543. Megalac is 9\% calcium and $89 \%$ fat.

use of the PDIFF option. Mean treatment and time effects are reported as least square means.

\section{RESULTS AND DISCUSSION}

One of the primary goals of transition cow care should be to maintain DMI before calving. On average, feed intake decreases by $30 \%$ in the days before calving (Grummer, 1995). In this study, cows in the treatment group did not exhibit the usual decline in appetite as calving approached (Figure 1A). Daily feed intake of control cows dropped by $19.5 \%$, from $16.4 \pm 1.3 \mathrm{~kg} / \mathrm{d}$ of DMI for wk -2 before calving to $13.5 \pm 1.3 \mathrm{~kg} / \mathrm{d}$ during wk -1 ( $P \leq 0.05$ for wk -1 compared with wk -2$)$. Cows on treatment maintained feed intake through calving at $16.0 \mathrm{~kg} / \mathrm{cow}$ per day $(P \leq 0.05$ for treatment $\times$ day $)$. Feed intake for either group did not increase signifi- cantly over wk -2 until wk 3 of lactation $(P>0.10)$. Body condition scores were not affected by treatments and averaged $3.4 \pm 0.13,3.3 \pm 0.16,2.7 \pm 0.15$, and 2.7 \pm 0.18 on a scale of 1 to 5 at d $-14,0,28$, and 70 , respectively. Likewise, BW did not differ and averaged $743 \pm 22.9,679 \pm 24.5,627 \pm 27.6$, and $618 \pm 28.9 \mathrm{~kg}$ at $\mathrm{d}-14,0,28$, and 70 , respectively.

There was no treatment effect on milk production the first $4 \mathrm{wk}$ of lactation (Figure 1B), or over the entire 305-d lactation, which averaged 12,025 $\pm 440 \mathrm{~kg}$ for the treatment cows compared with $11,629 \pm 440 \mathrm{~kg}$ for the controls. The yield of energy-corrected milk per kilogram of DMI was greater $(P \leq 0.05)$ for treatment cows during wk 2 postcalving (Figure 1C). This increase in feed conversion efficiency (3.1 kg of energy-corrected milk per kilogram of DMI at 14 DIM for treatment cows compared with 2.4 for the controls) was all the more 
Table 2. Nutrient composition of experimental diets. ${ }^{1}$

\begin{tabular}{lccc}
\hline Nutrient & -60 to -14 DIM & -14 to 0 DIM & 0 to 28 DIM \\
\hline DM, \% as fed & 56.9 & 53.24 & 57.19 \\
Crude protein, \% DM & 12.1 & 14.91 & 18.18 \\
ADF, \% DM & 28.8 & 20.92 & 21.03 \\
NDF, \% DM & 46.3 & 35.00 & 28.85 \\
Fat, \% DM & 3.66 & 3.54 & 4.11 \\
Ca, \% DM & 0.68 & 0.64 & 1.02 \\
P, \% DM & 0.39 & 0.42 & 0.46 \\
Mg, \% DM & 0.29 & 0.29 & 0.30 \\
Na, \% DM & 0.12 & 0.14 & 0.26 \\
Al, \% DM & 0.17 & 0.15 & 0.32 \\
K, \% DM & 1.06 & 1.11 & 1.13 \\
S, \% DM & 0.18 & 0.17 & 0.23 \\
Fe, ppm & 158 & 120 & 137 \\
Cu, ppm & 19.6 & 16 & 22 \\
Co, ppm & 0.12 & 0.10 & 0.12 \\
Mn, ppm & 76 & 67 & 67 \\
Zn, ppm & 55 & 44 & 51 \\
I, ppm & 0.40 & 0.34 & 0.42 \\
Se, ppm & 0.20 & 0.17 & 0.14 \\
Vit A, IU/kg & 1407 & 1068 & 4631 \\
Vit D, IU/kg & 281 & 213 & 926 \\
Vit E, IU/kg & 11.3 & 8.58 & 12.34 \\
\hline
\end{tabular}

${ }^{1}$ The same diet was fed both groups until $14 \mathrm{~d}$ before calving. Thereafter, both treatment and control diets at $-14 \mathrm{~d}$ to calving and from calving to $28 \mathrm{DIM}$ were formulated for similar concentrations of various nutrients.

noteworthy, given that at 7 and 28 DIM milk fat concentrations were significantly lower $(P \leq 0.02)$ for treatment cows compared with control cows (Figure 2A). This corroborates observations by Studer et al. (1993), where propylene glycol tended to lower milk fat, and by Schmidt and Schultz (1958) where sodium propionate supplemented cows had lower milk fat compared with controls.

Protein concentrations tended to be less $(P \leq 0.10)$ in milk from treatment cows compared with controls at 7 and 14 DIM (Figure 2B). Milk lactose concentrations tended to be greater $(P \leq 0.10)$ for treatment cows on every day measured and especially $(P \leq 0.07)$ on $\mathrm{d} 28$, when treatment had been discontinued for a week (Figure 2C). Greater milk lactose concentration, a response to feeding regimens rarely encountered in the literature, is interesting as some investigators contend that lactose drives milk production (Patton and Jensen, 1976). This trend would seem to be another indication that treatment cows are responding differently than controls, in a manner reflecting a higher energy status.

Concentrations of glucose (Figure 3A) in blood were greater for treatment cows overall $(P \leq 0.05)$. Of all days measured, the only day treatment cows did not have numerically greater concentrations of blood glucose was d 28, after treatments had been discontinued for $7 \mathrm{~d}$. Accordingly, insulin concentrations (Figure 3B) were greater $(P \leq 0.02)$ overall for treatment cows and were especially so at -7 prepartum $(P \leq 0.01)$. By 7 DIM, treatment and control cows had similar blood insulin concentrations. When interpreted in light of the similar blood glucose concentrations for treatment and control at $d-7$, the $75 \%$ greater insulin concentration in blood of treatment cows could indicate greater blood glucose clearance, and consequently improved energy status. This is supported by the observation that this sample was collected during the period of the maximum drop in feed intake by the control cows, whereas feed intakes were maintained in treatment cows. Greater blood insulin prepartum in treatment cows parallels the report by Baird et al. (1980), who infused propionate and observed higher insulin in multiparous dry cows (days to calving were not stated) with no change in blood glucose. We consider germane the observation by Brockman (1990) that propionate stimulates insulin secretion, although unlike other glucose substrates, propionate uptake is not insulin dependent.

Glucagon concentrations in blood (Figure 3C) did not show a treatment effect. In most mammals, the role of glucagon is the antithesis of insulin, to effect the mobilization of depot fat to meet energy needs. Typically, glucagon predominates when insulin levels are minimal, but the data here demonstrate the 2 hormones falling and rising in a similar fashion. This would suggest that in the cows in this trial, the role of glucagon appears complementary to that of insulin.

Though there was no overall effect of treatments on NEFA $(P>0.10)$, control cows had greater concentrations of NEFA in blood (Figure $4 \mathrm{~A})$ at $2(P \leq 0.02)$ and 7 DIM $(P \leq 0.03)$ compared with treatment cows. The 


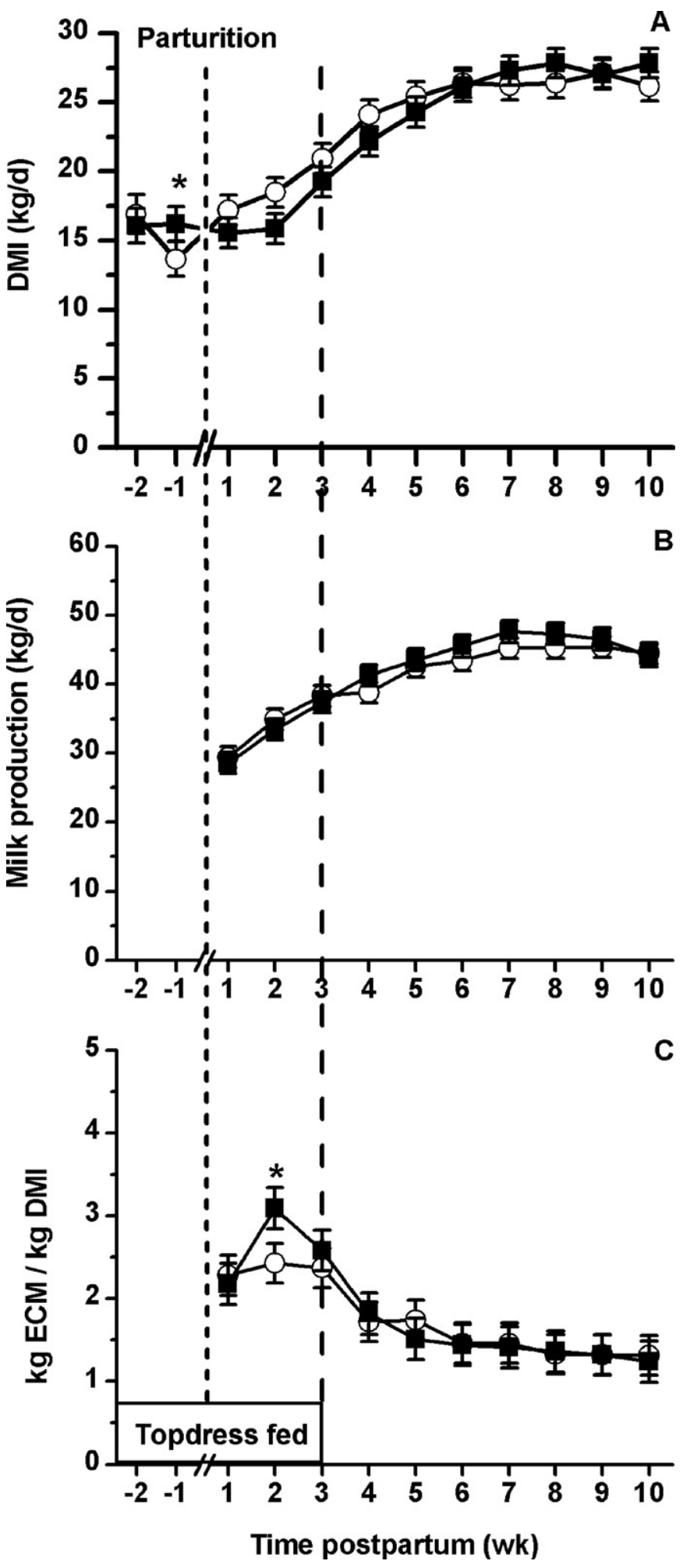

Figure 1. Average weekly DMI (A), milk production (B), and efficiency of production of energy-corrected milk (ECM, C) of cows fed control $(O)$ or treatment $(\boldsymbol{\square})$ top-dressed supplements. Differences at individual time points are indicated by $*(P \leq 0.05)$. There was an overall treatment effect $(P \leq 0.05)$ on efficiency of production of ECM, but the difference was evident only in wk 2 .
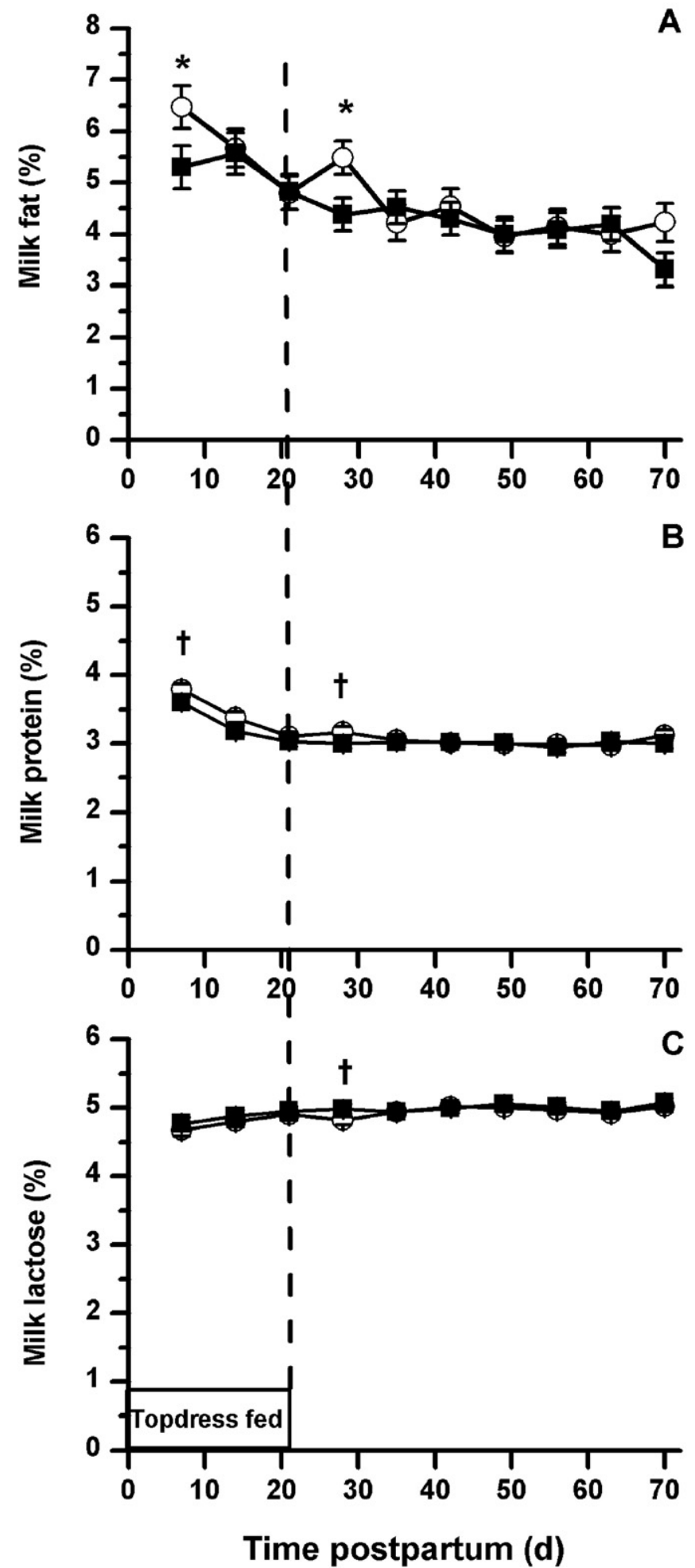

Figure 2. Concentrations of fat (A), protein (B), and lactose (C) in milk from cows fed control $(O)$ or treatment $(\square)$ top-dressed supplements. Differences at individual time points are indicated by $\dagger(P \leq$ $0.10)$ and $*(P \leq 0.05)$. Over all time points, treatment tended to affect lactose and protein $(P \leq 0.10)$. 


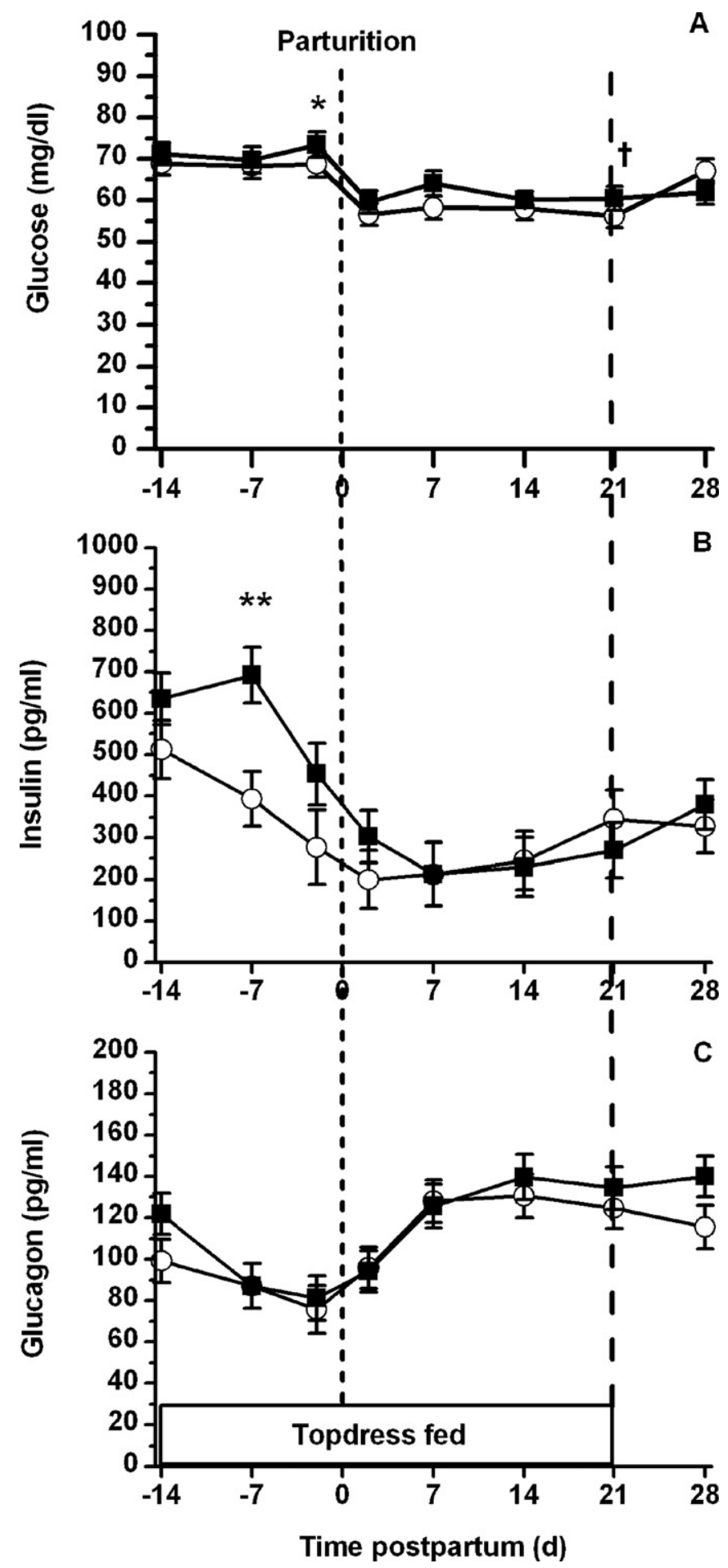

Figure 3. Concentrations of glucose (A), insulin (B), and glucagon (C) in blood of cows fed control $(O)$ or treatment $(\square)$ top-dressed supplements. Differences at individual time points are indicated by $\dagger(P \leq 0.10), *(P \leq 0.05)$, and $* *(P \leq 0.01)$. Over all time points there was a significant effect of treatment increasing glucose $(P \leq 0.05)$ and insulin $(P \leq 0.02)$.

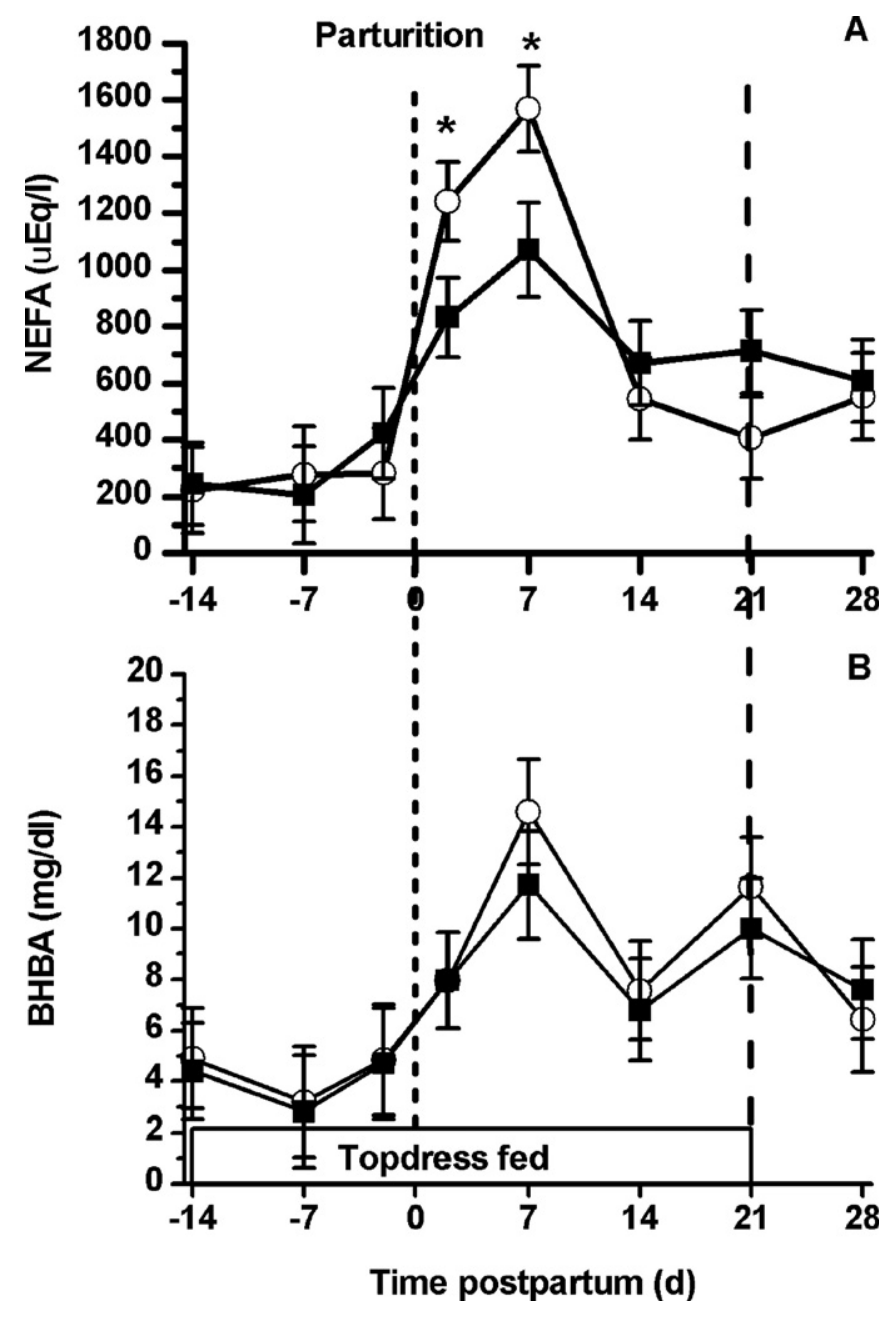

Figure 4. Concentrations of blood NEFA (A) and BHBA (B) of cows fed control $(\bigcirc)$ or treatment $(\square)$ top-dressed supplements. Differences at individual time points are indicated by $*(P \leq 0.05)$.

inverse relationship of blood glucose and NEFA was observed in all cows, with the greatest NEFA and least blood glucose observed at 2 and 7 DIM. Furthermore, of the 2 cow groups, treatment cows had the lesser NEFA and greater blood glucose concentrations, while control cows had the greater NEFA and lower blood glucose concentrations. Concentrations of BHBA in blood (Figure 4B) were not statistically different, although BHBA in control cows was $20 \%$ greater on d 7 than in treatment cows, when control cows exhibited the second lowest blood glucose and greatest NEFA concentrations.

Liver lipid concentrations did not show any significant treatment effect, although livers of control cows had numerically greater lipid (9.2 vs. $7.9 \pm 0.9 \%$, Figure $5 \mathrm{~A})$ concentrations on $\mathrm{d} 7$ than did livers of treatment cows. On that same day, concentrations of glycogen 


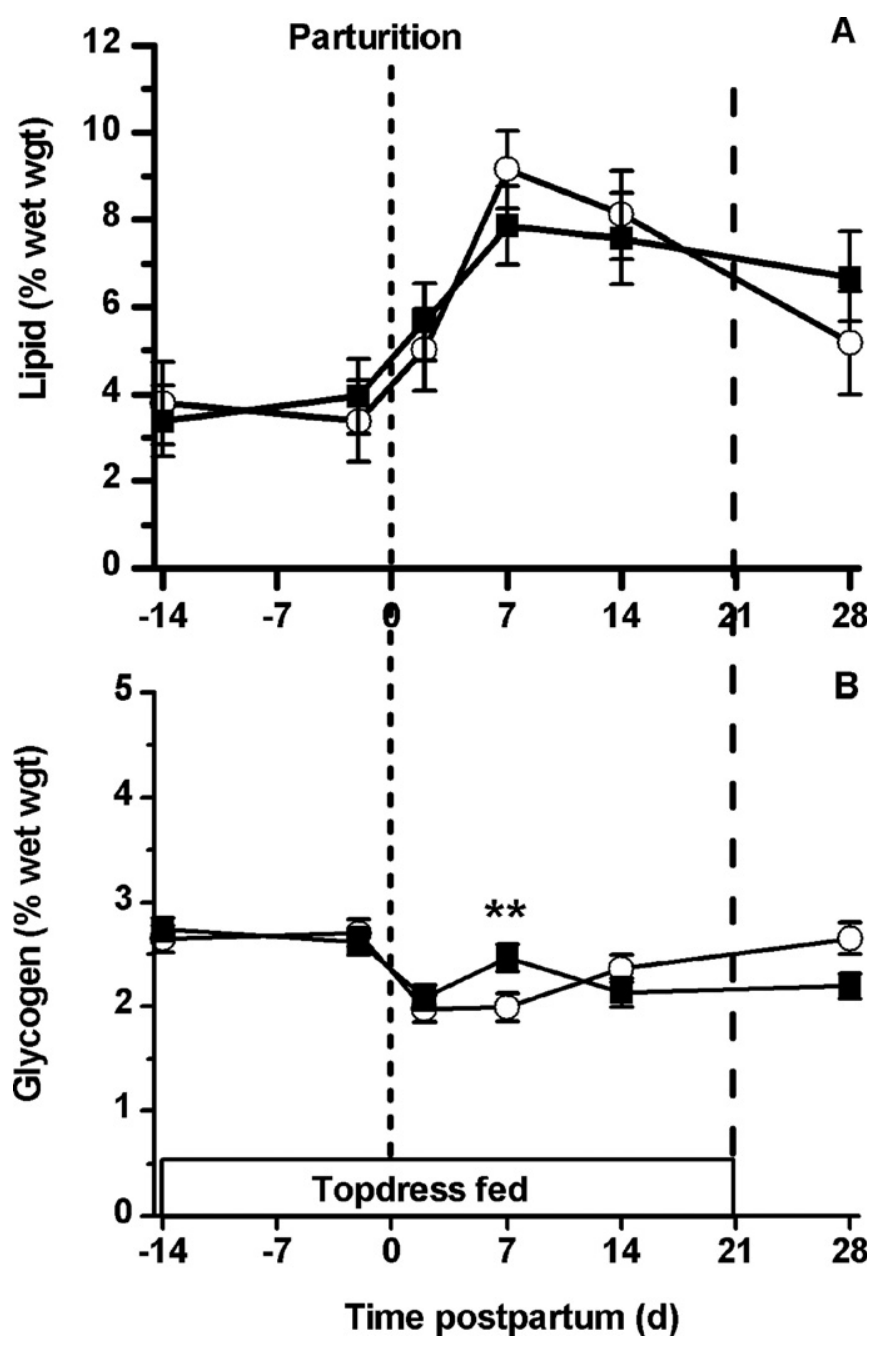

Figure 5. Concentrations of lipid (A) and glycogen (B) in livers of cows fed control $(O)$ or treatment $(\square)$ top-dressed supplements. Differences at individual time points are indicated by $* *(P \leq 0.01)$. There was a significant treatment $\times$ day interaction $(P \leq 0.01)$ for glycogen.

were significantly decreased (2.0 vs. $2.4 \pm 0.1 \%, P \leq$ 0.01 , Figure $5 B$ ) in livers of control cows compared with livers of treatment cows.

The main difference observed in health records was that fewer cows in the treatment group (4 vs. 6) exhibited signs of ketosis as determined by decreased appetites, urine ketones greater than $15 \mathrm{mg} / \mathrm{dL}$ (Ketostix, Bayer Corp., Tarrytown, NY), and odor of acetone on breath. Also, fewer total days of clinical ketosis (11 vs. 29 ) were observed in the treatment cows. These trends were not significant and no other trends were evident for other health variables. No treatment effect was observed for reproduction. Days to first service ( $82 \pm 8.9$ $\mathrm{d}$ for $\mathrm{C}$ vs. $85 \pm 8.7 \mathrm{~d}$ for $\mathrm{T}$ ) and services per conception
$(2.9 \pm 0.8$ for $\mathrm{C}$ vs. $3.2 \pm 0.8$ for $\mathrm{T})$ did not differ between treatments.

The treatment cows in this experiment showed indications of improved energy status compared with controls. The treatment supplement was unique in that it contained bypass fat and glucogenic precursors, and was fed both prepartum and postpartum. Most studies on feeding fat to transition cows involve either preor postcalving application, and report negative effects, especially for DMI. Control cows in this study had a typical drop in DMI prepartum, whereas treatment cows did not. A possible mechanism explaining our overall results is a 2 -fold and synergistic response of the cows fed fat with glucogenic precursors. The first part of this mechanism involves bypass fat, which enters the blood as chylomicrons and is more readily extracted by the mammary gland, which is replete with lipoprotein lipase (Havel, 1987). Also, less chylomicron fat is taken up by the liver, which is relatively devoid of lipoprotein lipase for chylomicron metabolism (Emery et al., 1992). Given the high energy needs of the mammary gland at transition, ameliorating this demand with dietary fat may down-regulate the signaling for depot fat mobilization, thus decreasing NEFA and liver fat accumulation. The second component of the proposed mechanism involves propionate, which is the major glucose precursor taken up by the ruminant liver, with the characteristic that it inhibits liver lipid oxidation (Lomax et al., 1983; Jesse et al., 1986; Armentano et al., 1991). Yet another aspect favoring propionate as an energy source is the distribution of the coenzyme A synthetase enzymes, essential for the activation of VFA before further metabolism. Propionyl CoA synthetase is found predominantly in the liver and kidney, major organs of gluconeogenesis, and its concentration is relatively much lower in the mammary and muscle tissue, where acetyl CoA synthetase predominates. (Cook et al., 1969). Propionyl CoA synthetase activity in cattle liver homogenates was reported to be 14 to 28 times that of rumen epithelium (Ash and Baird, 1973). Allocation of the VFA synthetase enzymes partitions uptake of the glucogenic propionate to organs of glucose synthesis, while directing acetate to tissues that use, store, or export lipids (Cook et al., 1969; Bergman, 1990).

It is unlikely that results observed in this study can be attributed to differences in caloric intake, although that possibility cannot be entirely discounted. With the same base ration, and fat supplementation identical, the difference in treatment and control groups reduces to the difference between $274 \mathrm{~g}$ of barley and $274 \mathrm{~g}$ of glucogenic substrate. Differences observed, therefore, indicate that the origin or derivation of the calories, and not just their quantity, is important. Ferre et al. (1978) reported that oral fat increased the glycemic 
effect of glucose precursors, and hypothesized that hepatic fatty acid oxidation yielded ATP, acetyl CoA, and NADH required for glucogenesis. Lomax et al. (1986) demonstrated the same phenomena in sheep hepatocytes, where fatty acids caused a rise in mitochondrial NADH:NAD+ ratios, and stimulated the entry of propionate carbon into the glucogenic pathway. We propose that the results reported here, indicating improved energy status for transition cows fed fat and glucogenic precursors, are explained by a similar gain in energetic metabolism.

\section{CONCLUSIONS}

The combination of glucogenic precursors and fat in the product tested had a beneficial effect on several measures known to be critical for the transition cow. Feed efficiency, blood glucose, insulin, and NEFA all indicated, significantly, a more positive energy balance for treatment cows. Precalving DMI, total lactation milk, blood ketones, liver lipid, and liver glycogen all numerically favored the supplement treatment compared with the control cows that received a fat-barley supplement. These effects are attributed to the presence of glucogenic precursors in conjunction with fat and not the fat alone in the product, considering the control diet provided the same type and amount of fat. The data imply that when glucogenic precursors are fed in the presence of dietary fat there is a synergistic beneficial effect on the transition cow.

\section{ACKNOWLEDGMENTS}

The authors would like to express their gratitude to the farm crew at the South Dakota State University Dairy Research and Training Facility and to Pete Linke, in particular, for assistance in care and feeding of the research cows. This research was sponsored, in part, by Pestell Inc., New Hamburg, ON, Canada and the South Dakota Agricultural Experiment Station.

\section{REFERENCES}

Armentano, L. E., R. R. Grummer, S. J. Bertics, T. C. Skaar, and S. S. Donkin. 1991. Effect of energy balance on hepatic capacity for oleate and propionate metabolism and triglyceride secretion. J. Dairy Sci. 74:132-139.

Association of Official Analytical Chemists. 1997. Official Methods of Analysis. 16th ed. AOAC Intl. Gaithersburg, MD.

Ash, R., and G. D. Baird. 1973. Activation of volatile fatty acids in bovine liver and rumen epithelium. Evidence for control by autoregulation. Biochem. J. 136:311-319.

Baird, G. D., A. Lomax, H. W. Symonds, and S. R. Shaw. 1980. Net hepatic and splanchnic metabolism of lactate, pyruvate and propionate in dairy cows in vivo in relation to lactation and nutrient supply. Biochem. J. 186:47-57.
Bergman, E. N. 1990. Energy contribution of volatile fatty acids from the gastrointestinal tract in various species. Physiol. Rev. 70:567-590.

Brockman, R. P. 1990. Effect of insulin on the utilization of propionate in gluconeogenesis in sheep. Br. J. Nutr. 64:95-101.

Christensen, J. O., R. R. Grummer, F. E. Rasmussen, and S. J. Bertics. 1997. Effect of method of delivery of propylene glycol on plasma metabolites of feed-restricted cattle. J. Dairy Sci. 80:563-568.

Cook, R. M., S. C. Liu, and S. Quraishi. 1969. Utilization of volatile fatty acids in ruminants. III. Comparison of mitochondrial acyl coenzyme A synthetase activity and substrate specificity in different tissues. Biochemistry 8:2966-2969.

Derling, L. E., D. E. Brown, L. Castle, and L. Kelly. 1987. Muscle glycogen: comparison of iodine binding and enzyme digestion assays and application to meat samples. Meat Sci. 20:167-177.

Drackley, J. K. 1999. Biology of dairy cows during the transition period: the final frontier. J. Dairy Sci. 82:2259-2273.

Emery, R. S., J. S. Liesman, and T. H. Herdt. 1992. Metabolism of long chain fatty acids by ruminant liver. J. Nutr. 122:832-837.

Ferre, P., J. P. Pegorier, E. B. Marliss, and J. R. Girard. 1978. Influence of exogenous fat and gluconeogenic substrates on glucose homeostasis in the newborn rat. Am. J. Physiol. 234:E129-E136.

Grum, D. E., J. K. Drackley, R. S. Younkers, D. W. LaCount, and J. J. Veenhuizen. 1996. Nutrition during the dry period and hepatic metabolism of periparturient dairy cows. J. Dairy Sci. 79:1850-1864.

Grummer, R. R. 1995. Impact of changes in organic nutrient metabolism on feeding the transition dairy cow. J. Anim. Sci. 73:2820-2833.

Grummer, R. R., J. C. Winkler, S. J. Bertics, and V. A. Studer. 1994. Effect of propylene glycol dosage during feed restriction on metabolites in blood of prepartum Holstein heifers. J. Dairy Sci. 77:3618-3623.

Havel, R. J. 1987. Lipid transport function of lipoproteins in blood plasma. Am. J. Physiol. 253(Endocrinol. Metab. 16):E1-E5.

Jerred, M. J., D. J. Carroll, D. K. Combs, and R. R. Grummer. 1990. Effect of fat supplementation and immature alfalfa to concentrate ratio on lactation performance of dairy cows. J. Dairy Sci. 73:2842-2854.

Jesse, B. W., R. S. Emery, and J. W. Thomas. 1986. Control of bovine hepatic fatty oxidation. J. Dairy Sci. 69:2290-2297.

Lomax, M. A., I. A. Donaldson, and C. I. Pogson. 1983. The control of fatty acid metabolism in liver cells from fed and starved sheep. Biochem. J. 214:553-560.

Lomax, M. A., I. A. Donaldson, and C. I. Pogson. 1986. The effect of fatty acids and starvation on the metabolism of gluconeogenic precursors by isolated sheep liver cells. Biochem. J. 240:277-280.

Mills, S. E., D. C. Beitz, and J. W. Young. 1986. Characterization of metabolic changes during protocol for inducing lactation ketosis in dairy cows. J. Dairy Sci. 69:352-361.

Patton, R. S., and G. Poley. 1996. Understanding of energy status of the prepartum cow improves. Feedstuffs 68:24.

Patton, S., and R. G. Jensen. 1976. Biomedical Aspects of Lactation. Pergamon Press, New York, NY.

SAS/STAT. 1996. Software. Changes and Enhancements Through Release 6.11. 1996. SAS Institute., Inc., Cary, NC.

Schmidt, G. H., and L. H. Schultz. 1958. Effect of feeding sodium propionate on milk and fat production, roughage consumption, blood sugar, and blood ketones of dairy cows. J. Dairy Sci. 41:169-175.

Smith, T. R., A. R. Hippen, D. C. Beitz, and J. W. Young. 1997. Metabolic characteristics of induced ketosis in normal and obese dairy cows. J. Dairy Sci. 80:1569-1581.

Studer, V. A., R. R. Grummer, S. J. Bertics, and C. K. Reynolds. 1993. Effect of prepartum propylene glycol administration on periparturient fatty liver in dairy cows. J. Dairy Sci. 76:29312939.

Williamson, D. H., and J. Melanby. 1974. D-(-)-3-hydroxybutyrate. Page 1836 in Methods and Enzymatic Analysis. Vol. 4. 2nd ed. H.U. Bergmeyer, ed. Academic Press, London, UK. 